\title{
DEKOMPOSISI BERBAGAI JENIS BAHAN ORGANIK DENGAN Trichoderma viride (Isolat T1sk) UNTUK MENINGKATKAN PERTUMBUHAN BIBIT PISANG
}

\author{
Dini Puspita Yanti ${ }^{1}$ \\ ${ }^{1}$ Staf Pengajar Program Studi Agroteknologi Universitas Graha Nusantara, \\ Padangsidimpuan, Sumatera Utara
}

\begin{abstract}
ABSTRAK
Penelitian bertujuan untuk mendapatkan bahan organik terbaik yang didekomposisi oleh Trichoderma viride untuk meningkatkan pertumbuhan bibit pisang. Rancangan yang digunakan adalah Rancangan Acak Lengkap (RAL) yang terdiri dari 7 perlakuan dan 5 ulangan, yaitu kotoran ayam didekomposisi oleh $T$. viride, kotoran sapi didekomposisi oleh T. viride, kompos jerami didekomposisi oleh T. viride, kotoran ayam tanpa didekomposisi oleh $T$. viride, kotoran sapi tanpa didekomposisi oleh $T$. viride, kompos jerami tanpa didekomposisi oleh $T$. viride, kontrol (substrat ampas tebu yang diinokulasi oleh $T$. viride). Parameter yang diamati adalah pertumbuhan bibit pisang (tinggi tanaman dan jumlah daun) Hasil penelitian menunjukkan bahwa aplikasi bahan organik yang didekomposisi dan tanpa didekomposisi oleh $T$. viride berpengaruh terhadap pertumbuhan bibit pisang. Hal ini dapat dilihat dari pertambahan tinggi tanaman setiap minggunya.
\end{abstract}

Kata kunci : Bahan organik, bibit pisang, Trichoderma viride, dekomposisi

\section{PENDAHULUAN}

Pisang merupakan tanaman hortikultura yang dapat tumbuh di berbaga tempat dan mempunyai nilai ekonomis yang cukup tinggi. Produksi pisang dari tahun ke tahun mengalami peningkatan. Meningkatnya permintaan buah pisang untuk kebutuhan lokal maupun ekspor diikuti dengan meningkatnya kebutuhan akan bibit pisang yang berkualitas. Pisang mempunyai nilai gizi yang cukup baik yaitu sebagai sumber karbohidrat, protein, dan energi dan memiliki kandungan vitamin C, B, kalsium dan kandungan lemak yang cukup (Sriharti 2008).

Trichoderma merupakan salah satu jenis jamur yang banyak digunakan saat ini. Beberapa peranan Trichoderma di alam adalah sebagai agens hayati, pengurai bahan organik, dan meningkatkan pertumbuhan tanaman. Menurut (Harman, 2000 ; Harman et al. 2004a) Trichoderma dapat meningkatkan pertumbuhan dan perkembangan akar, produktivitas tanaman, resistensi terhadap stres abiotik serta penyerapan dan pemanfaatan nutrisi.

Beberapa hasil penelitian diketahui bahwa agens hayati seperti Trichoderma juga dapat berfungsi sebagai dekomposer. Jamur Trichoderma berperan sebagai dekomposer dalam proses pengomposan untuk mengurai bahan organik seperti selulosa menjadi senyawa glukosa. Keunggulan lain Trichoderma yaitu dapat digunakan sebagai biofungisida yang ramah lingkungan (Soesanto, 2004). Trichoderma spp. sebagai dekomposer membantu mendegradasi bahan organik sehingga lebih tersedianya hara bagi pertumbuhan tanaman (EPA. 2000; Viterbo et al. 2007).

Aplikasi jamur Trichoderma spp. dalam skala yang lebih luas diperlukan perbanyakan secara massal dengan menggunakan bahan organik, seperti pupuk kandang dan limbah pertanian. Bahan organik berupa serasah tanaman, kompos dan kotoran hewan sangat penting untuk kehidupan mikroba (Moraj et al. 2009). Anom (2008) melaporkan bahwa 
pemberian Tricho-kompos jerami dengan dosis 20 ton/ha dapat memberikan efek yang baik untuk pertumbuhan dan produksi pada tanaman sawi hijau. Tujuan penelitian ini adalah untuk mendapatkan bahan organik terbaik yang didekomposisi oleh Trichoderma viride untuk meningkatkan pertumbuhan bibit pisang.

\section{METODE PENELITIAN}

Penelitian ini telah dilaksanakan di rumah kaca Fakultas Pertanian Universitas Andalas Padang.

Rancangan yang digunakan dalam penelitian ini adalah Rancangan Acak Lengkap (RAL) yang terdiri atas 7 perlakuan dan 5 ulangan. Perlakuan adalah berbagai bahan organik yang didekomposisi dan tanpa didekomoposisi oleh $T$. viride selama 14 hari sebagai berikut :

A. Kotoran ayam didekomposisi oleh $T$. viride

B. Kotoran sapi didekomposisi oleh $T$. viride

C. Kompos jerami didekomposisi oleh $T$. viride

D. Kotoran ayam tanpa didekomposisi oleh $T$. viride

E. Kotoran sapi tanpa didekomposisi oleh T. viride

F. Kompos jerami tanpa didekomposisi oleh $T$. viride

G. Kontrol (substrat ampas tebu yang diinokulasi oleh $T$. viride)

Data diolah menggunakan analisis ragam dan uji Tukey pada taraf nyata $5 \%$.

\section{Pelaksanaan}

Persiapan bahan organik

Bahan yang digunakan yaitu : kotoran sapi, kotoran ayam, dan jerami yang diperoleh dari UPTD perkebunan Gadut. Kriteria kotoran hewan yang digunakan yaitu yang sudah kering dan tidak berbau, dan untuk jerami digunakan 1 bulan setelah padi di panen. Masingmasing bahan organik diambil sebanyak 4 $\mathrm{kg}$ dan ditempatkan di ruangan yang terlindung dari hujan dan sinar matahari langsung.

\section{Persiapan dan perbanyakan Trichoderma viride}

Peremajaan $T$. viride tanah diambil dengan menggunakan spatula, kemudian diletakkan di atas cawan Petri yang telah berisi medium PDA baru dan diinkubasi selama 3 hari. Jamur yang tumbuh dipotong dengan menggunakan cork borer dan dipindahkan pada cawan Petri yang telah berisi medium PDA dan diinkubasi selama 6 hari.

Sterilisasi tanah dan aplikasi berbagai jenis bahan organik yang telah didekomposisi dan tanpa dodekomposisi oleh Trichoderma viride serta penanaman bibit pisang

Tanah yang digunakan berasal dari kebun percobaan Fakultas Pertanian. Tanah disterilkan menggunakan uap panas selama satu setengah jam pada suhu 150 ${ }^{0} \mathrm{C}$. Setelah dingin dimasukkan ke dalam masing-masing polybag sebanyak $5 \mathrm{~kg}$. Bahan organik yang didekomposisi dan tanpa didekomposisi oleh $T$. viride diintroduksi sebanyak $25 \mathrm{~g} /$ polybag dan diinkubasi satu minggu.

Bibit pisang kultivar Ambon Kuning yang digunakan adalah bibit kultur jaringan berasal dari Balai Penelitian Tanaman Buah Tropika Solok yang sudah diaklimatisasi selama 60 hari.

\section{Pemeliharaan}

Penyiraman dilakukan sesuai dengan kebutuhan tanaman. Hama dan gulma dikendalikan secara mekanik.

\section{Tinggi tanaman pisang $(\mathbf{c m})$}

Pengamatan tinggi tanaman dilakukan sekali seminggu dengan cara mengukur tanaman mulai dari leher akar sampai daun terpanjang. Tinggi tanaman diukur mulai saat tanaman berumur 1 minggu sampai $8 \mathrm{mst}$. 
Jumlah daun (helai)

Jumlah daun dihitung bersamaan dengan tinggi tanaman.

\section{HASIL DAN PEMBAHASAN}

\section{Hasil}

Tinggi bibit pisang

Hasil analisis ragam terhadap tinggi bibit pisang pada masing-masing perlakuan dapat dilihat pada Tabel 1.

Tabel 1 Tinggi bibit pisang yang diperlakukan dengan berbagai jenis bahan organik (2 bulan setelah tanam)

\begin{tabular}{|c|c|c|}
\hline Perlakuan & $\begin{array}{c}\text { Tinggi bibit } \\
\text { pisang } \\
\text { (cm) }\end{array}$ & $\begin{array}{c}\text { Efektivitas } \\
(\%)\end{array}$ \\
\hline Kotoran ayam tanpa didekomposisi oleh $T$. viride & 82,80 a & 17,81 \\
\hline Kotoran ayam didekomposisi oleh $T$. viride & 80,90 a & 15,11 \\
\hline Kompos jerami tanpa didekomposisi oleh $T$. viride & $77,10 \mathrm{ab}$ & 9,70 \\
\hline Kotoran sapi tanpa didekomposisi oleh $T$. viride & $76,04 \mathrm{ab}$ & 8,19 \\
\hline Kotoran sapi didekomposisi oleh $T$. viride & $75,88 \mathrm{ab}$ & 7,96 \\
\hline Kontrol (substrat ampas tebu yang diinokulasi $T$. viride) & $70,28 \quad b$ & \\
\hline Kompos jerami didekomposisi oleh $T$. viride & 69,96 & $-0,45$ \\
\hline
\end{tabular}

$\mathrm{KK}=5,55$

Angka-angka yang diikuti oleh huruf kecil yang sama pada kolom yang sama menunjukkan hasil berbeda tidak nyata antar perlakuan pada taraf 5\% menurut uji Tukey.

Dari Tabel 1 terlihat bahwa aplikasi berbagai jenis bahan organik yang didekomposisi dan tanpa didekomposisi oleh $T$. viride dapat meningkatkan tinggi bibit tanaman pisang. Masing-masing perlakuan ini berbeda tidak nyata sesamanya tetapi berbeda nyata dengan kontrol. Tinggi bibit tanaman pisang tertinggi terdapat pada kotoran ayam tanpa didekomposisi oleh $T$. viride dan kotoran ayam didekomposisi oleh $T$. viride yaitu
$82,80 \mathrm{~cm}$ dan $80,90 \mathrm{~cm}$ dengan efektivitas masing-masing adalah $17,81 \%$ dan $15,11 \%$. Pertumbuhan bibit tanaman pisang setiap minggunya dapat dilihat pada Gambar 1.

Dari Gambar 1 terlihat bahwa tinggi bibit pisang setiap minggunya selalu meningkat. Pertumbuhan bibit pisang yang paling tinggi terdapat pada perlakuan kotoran ayam tanpa didekomposisi oleh $T$. viride.
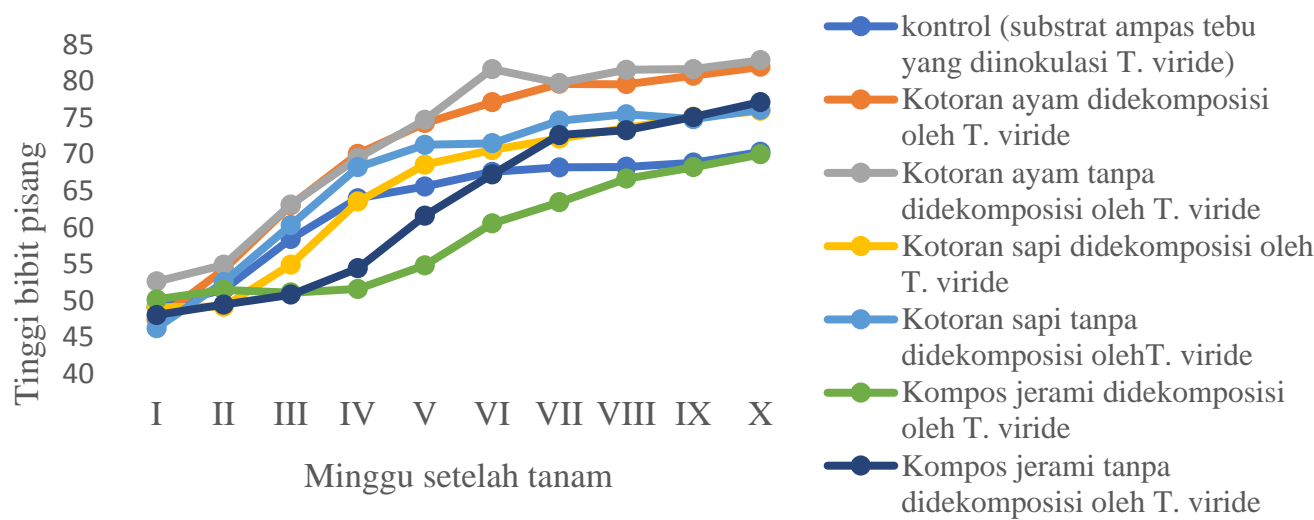

Gambar 1. Tinggi bibit pisang yang diaplikasi dengan berbagai jenis bahan organik 
Jumlah daun bibit pisang

Hasil analisis sidik ragam jumlah

daun bibit pisang dengan perlakuan dengan berbagai jenis bahan organik yang didekomposisi dan tanpa didekomposisi oleh T. viride dapat dilihat pada Tabel 2.

Tabel 2. Jumlah daun bibit pisang yang diperlakukan dengan berbagi jenis bahan organik ( 2 bulan setelah tanam)

\begin{tabular}{lcc}
\hline \multicolumn{1}{c}{ Perlakuan } & $\begin{array}{c}\text { Jumlah } \\
\text { daun } \\
\text { (helai) }\end{array}$ & $\begin{array}{c}\text { Efektivitas } \\
(\%)\end{array}$ \\
\hline Kotoran sapi didekomposisi oleh T. viride & 11,20 a & 1,81 \\
Kontrol (substrat ampas tebu yang diinokulasi T. viride) & 11,00 a & \\
Kompos jerami tanpa didekomposisi oleh T. viride & 11,00 a & \\
Kotoran ayam didekomposisi oleh T. viride & 10,80 a & $-1,81$ \\
Kotoran sapi tanpa didekomposisi oleh T. viride & 10,80 a & $-1,81$ \\
Kompos jerami didekomposisi oleh T. viride & 10,80 a & $-1,81$ \\
Kotoran ayam tanpa didekomposisi oleh T. viride & 10,00 a & $-9,09$ \\
\hline kk=6.82 & & \\
\hline
\end{tabular}

Angka-angka yang diikuti oleh huruf kecil yang sama pada kolom yang sama menunjukkan hasil berbeda tidak nyata antar perlakuan pada taraf $5 \%$ menurut uji Tukey

Tabel 2 menunjukkan bahwa aplikasi berbagai jenis bahan organik yang didekomposisi dan tanpa didekomposisi oleh $T$. viride belum memberikan pengaruh yang nyata terhadap jumlah daun bibit pisang.

\section{Pembahasan}

Aplikasi bahan organik yang didekomposisi dan tanpa didekomposisi oleh $T$. viride berpengaruh terhadap peningkatan tinggi bibit pisang (Tabel 1), tetapi tidak terlalu berpengaruh terhadap jumlah daun bibit pisang (Tabel 2). Brady dan Weil (2002) melaporkan bahwa bahan organik berperan penting dalam memperbaiki kesuburan tanah. Peranan bahan organik bagi tanah berkaitan dengan perubahan sifat-sifat tanah, yaitu sifat fisik, biologi dan sifat kimia tanah. Haris (2002) juga melaporkan bahwa pupuk organik diketahui memiliki kelebihan yang dapat memperbaiki struktur tanah, menambah kandungan humus, memperbaiki kehidupan mikroorganisme dalam tanah, dan memperbaiki kualitas hasil pertanian. Bahan organik berupa serasah tanaman, kompos dan pupuk kandang sangat penting untuk kehidupan mikroba (Moraj, et al., 2009). Menurut Suridikarta et al., (2006) bahwa pupuk kandang berperan dalam kesuburan tanah dengan menyediakan zat dan nutrien, seperti nitrogen yang dibutuhkan mikroba dalam tanah. Riley et al., (2008) dan Dinesh et al., (2010) juga melaporkan bahwa bahwa aplikasi bahan organik dapat memperbaiki struktur tanah, meningkatkan kapasitas menahan air, dan meningkatkan kehidupan biologi tanah.

\section{KESIMPULAN}

Aplikasi bahan organik yang didekomposisi dan tanpa didekomposisi oleh $T$. viride berpengaruh terhadap pertumbuhan bibit pisang. Hal ini dapat dilihat dari pertambahan tinggi setiap minggunya.

\section{DAFTAR PUSTAKA}

Anom E. 2008. Efek Residu pemberian Tricho-kompos jerami padi terhadap pertumbuhan dan produksi sawi hijau (Brassica juncea. L). Laboratorium Ilmu 
Tanah Fakultas Pertanian UNRI. Vol. 7 No 2 - 12.

Brady NC, Well R R. 2002. The nature and properties of soils, I3'h ed. Prentice-Hall. Upper Saddle Rivers.

Dinesh R, Srinivasan V, Hamza S, Manjusha A. 2010. Short-term incorporation of organik manures and biofertilizers influences biochemical and microbial characteristics of soils under an annual crop turmeric (Curcuma longa L.). Bioresource Technol. 101: 4697-4702.

EPA. 2000. Trichoderma hazianum Rivai Strain T-39 (119200) Technical Dokument http://www .epa.gov/pesticides/search.htm.

Haris A, Adnan AM. 2000. Mikoriza dan manfaatnya. Balai Penelitian Tanaman Serelia. Prosiding Seminar Ilmiah dan Pertemuan Tahunan PEI dan PFI XVI Komda Sul-Sel.
Moraj R, Paredes C, Bustamantea MA, Marhuenda-Egea F, Bernal MP. 2009. Utilisation of manure composts by high-value crops: Safety and environmental challenges. Bioresource Technology. 100 (22)

Riley H, Pommeresche R, Eltun R, Hansen S, Korsaeth A. 2008. Soil structure, organik matter and earthworm activity in a comparison of cropping systems with contrasting tillage, rotations, fertilizer levels and manure use. Agric. Ecosyst. Environ. 124: 275-284.

Soesanto L. 2004. Ilmu penyakit pascapanen : Sebuah Pengantar. Purwokerto (ID): Universitas Jenderal Soedirman.

Suriadikarta, Simanungkalit. 2006. Pupuk organik dan pupuk hayati. Balai Besar Penelitian dan Pengembangan Sumberdaya Lahan Pertanian. Bogor. http//balittanah.litbang.deptan.g o.id. 